\title{
Fractured patella in children: Preservation of the patellar dimensions
}

\author{
Çocuklarda diz kapă̆ı kırıkları: Dizkapağı boyutlarının korunması
}

\author{
Elsayed Ibraheem Elsayed Massoud
}

\begin{abstract}
Objectives: The progressive understanding of the mechanical function of the patella makes preservation of its geometry is mandatory, particularly during its reconstruction. Objectives of this study were to compare the patellar dimensions after surgical and conservative treatment for patellar fractures in children and to present influence of the changes in the patellar dimensions on the knee motions.
\end{abstract}

Materials and methods: Two groups of children with patellar fractures their ages at time of injury averaged 12 years. One group included five children, was treated surgically using of the inter-fragmentary wiring technique and the other group that includes seven children was treated conservatively. Patients were prospectively followed for a period-averaged 65.5 months, the knee function and the patellar dimensions were assessed clinically and radiographically.

Results: The group was treated surgically reported insignificant increase in the patellar longitudinal length and reported no extension lag; however, reported average $9^{\circ}$ flexion deficit, which is possibly correlated to radiographic increase of the patellar thickness. The group was treated conservatively reported significant increase in the patellar longitudinal length and reported extension lag averaged $4.3^{\circ}$ and flexion deficit averaged $7.14^{\circ}$.

Conclusions: Surgical treatment preserved to great extent the longitudinal patellar length but it failed to preserve the patellar thickness particularly in the comminuted patellar fractures. The patellar elongation caused extension lag and flexion deficit while the mere increase of the patellar thickness produced flexion deficit without extension lag.

Key words: Patella, dimensions, fracture, knee motion, children

\section{ÖZET}

Amaç: Diz kapağının mekanik fonksiyonlarının giderek daha iyi anlaşılması, onun geometrisini özellikle tamiri sırasında korumayı zorunlu kılmaktadır. Bu çalışmanın amacı, çocuklarda diz kapağı kırığı için uygulanan cerrahi ve konservatif tedavi sonrası diz kapağı boyutlarını karşılaştırmak ve diz kapağı boyutlarındaki değişikliklerin diz kapağı hareketlerine etkisini göstermektir.

Gereç ve yöntem: Yaş ortalaması 12 yıl olan iki grup diz kapağı kırığı olan çocuk diz yaralanması sırasında karşılaştırıldı. İlk grup fragmentleri cerrahi olarak telle bağlama tekniği ile tedavi edilen beş çocuk, diğer grup ise konservatif tedavi uygulanan yedi çocuğu içermekte idi. Hastalar prospektif olarak 65.5 ay süreyle izlendi.

Bulgular: Cerrahi tedavi yapılan grupta diz kapağı uzunluğunda önemsiz bir artış oldu ve ekstansiyon kısıtııı̆ı oluşmadı. Ancak cerrahi grupta muhtemelen diz kapağı kalınlığındaki radyografik artışla bağıntılı olarak $9^{\circ}$ fleksiyon kaybı gözlendi. Konservatif tedavi edilen grupta diz kapağı uzunluğunda anlamlı artış ve $4,3^{\circ}$ ekstensiyon kaybı ve $7,14^{\circ}$ fleksiyon kaybı gözlendi.

Sonuç: Cerrahi tedavi diz kapağı uzunluğunu büyük oranda korumakla birlikte, kalınlığını korumada özellikle parçalanmış kırıklarda başarısız oldu. Diz kapağı germesi ekstansiyon kısıtııı̆ı ve fleksiyon kaybına yol açarken; diz kapağı kalınlığındaki hafif artış ekstansiyon kısıtlılığı olmaksızın fleksiyon kaybına yol açtı.

Anahtar kelimeler: Diz kapağı, boyut, kırık, diz hareketleri, çocuk 


\section{INTRODUCTION}

The patella provides a mechanical advantage beyond mere linkage between the quadriceps and the patellar tendons. ${ }^{1}$ Dimensions of the patella, namely the patellar longitudinal length and the patellar thickness, have catch attentions of many authors because of its importance for the mechanical function of the extensor mechanism. Distortion of the patellar dimensions precludes restoration of the optimal length of the extensor mechanism, which is essential for knee flexion as well as knee extension. ${ }^{2-4}$ In view of that, concept of just restoration of continuity of the extensor mechanism for treatment of patellar fracture seems inappropriate.

Excluding patellectomy, that has received serious objections, ${ }^{1,5}$ methods of treatment of the patellar fractures include the conservative treatment and many surgical techniques. Based on both of the anatomical characteristics of children's patella and the studies that evaluated the fixation techniques 6-8, we assumed that the inter-fragmentary wiring is the most suitable technique.
The present study hypothesized that the surgical fixation can neutralize the stresses applied on the fractured patella. Thereby the patellar dimensions will be preserved.

Aims of the study were of two folds: firstly, to compare the patellar dimensions after surgical and conservative treatment for patellar fractures in children; secondly, to find out influence of changes occurred in the patellar dimensions on the knee motion.

\section{MATERIALS AND METHODS}

During the period from August 2002 to April 2008, we have surgically treated and prospectively followed a group of five children with patellar fractures. During the study period, we followed another group of seven children were treated conservatively elsewhere. Ages of the patients at time of injury averaged 12 years (range: 10-15). The vast majority of the patients are males (75\%); the base line data of patients are listed in Table 1. Parents agreed participation and the local ethics committee approved the study.

Table 1. Baseline data for two groups of children with fractured patella

\begin{tabular}{ccccccccc}
\hline Case no & Surgical group & \multicolumn{1}{c}{} & \multicolumn{4}{c}{ Conservative group } \\
\cline { 2 - 9 } & Age (years) & Sex & Side & Fracture pattern & Age (years) & Sex & Side & Fracture pattern \\
\hline 1 & 13 & Male & Right & Comminuted & 10 & Female & Right & Comminuted \\
2 & 15 & Female & Left & Transverse & 10 & Male & Left & Lower pole \\
3 & 12 & Male & Left & Comminuted & 11 & Female & Right & Transverse \\
4 & 11 & Male & Right & Longitudinal & 11 & Male & Left & Comminuted \\
5 & 15 & Male & Right & Lower pole & 14 & Male & Right & Upper pole \\
6 & & & & & 12 & Male & Right & Transverse \\
7 & & & & & 10 & Male & Right & Comminuted \\
\hline
\end{tabular}

The group that was surgically treated presented by recent history of trauma. Physical examination revealed local tenderness, knee effusion, high-riding patella and loss of the active knee extension. The group that was conservatively treated presented by knee pain and swelling. They declared that they were treated immediately in above knee cast for a period-averaged 4.5 weeks (range: 4-6). Physical examination revealed minimal knee effusion, wasting of the thigh and limitation of the knee motion. Anteroposterior and lateral radiographs of the af- fected knee were made for surgical group at the arrival to assign existence of the fracture, its pattern and presence of associated injuries. In the conservative group, the post-inclusion radiographs revealed healed patellar fractures. The fracture patterns were assigned from the post injury radiograph.

\section{Operative technique}

Under general anaesthesia, with a tourniquet applied, the patella is exposed through a midline lon- 
gitudinal incision. Patellar fragments, which look like pieces of thick cartilage filled with a layer of bone, are identified and reduced to its anatomical position. The articular surface of the patella is palpated to ensure its continuity and smoothness. Using of a drill bit $2.2 \mathrm{~mm}$, tunnels is created through the osseous skeleton of the patellar fragments. A circlage wire its diameter $1.0 \mathrm{~mm}$ is passed through the tunnels. In the comminuted fracture (Fig. 1), some fragments have frayed osseous skeleton therefore the wire is passed through it without prior drilling. The circlage is knotted without tightness to avoid overlapping of the fragments or slippage of the wire through the frayed osseous skeleton. The reticular tear is repaired, the skin is closed and high above knee cast is applied with the knee flexed to about $15^{\circ}$ for 4 weeks. The circlage wire was removed within the second postoperative year.

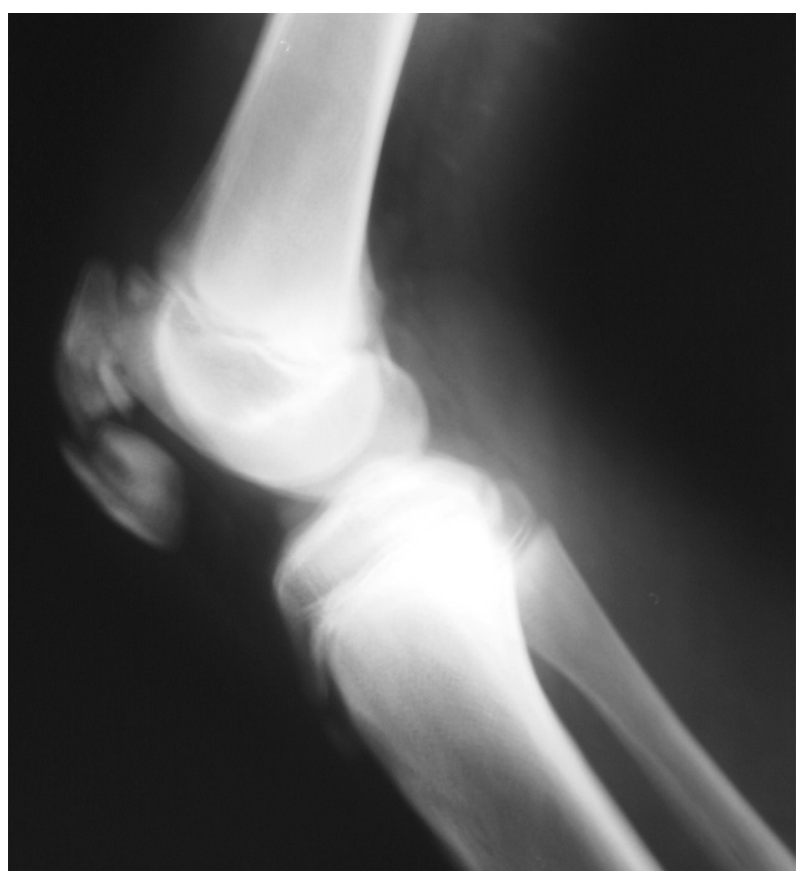

Figure 1. A lateral radiograph for left knee of a 12-yearold male. The patella shows comminuted fracture

Both groups were received a rehabilitation program that was stopped when the quadriceps muscles regained its maximum strength and the thigh girth nearly equalized the contralateral.

Follow-up examinations were carried out every other week for 12 weeks and then at 4,6 and 12 months post arrival. After the first year, patients were examined twice per year.

\section{Outcome measures:}

\section{Clinical assessment}

Ranges of active knee motion were measured with a goniometer and thighs girths $(15 \mathrm{~cm}$ above the tibial tuberosity) were measured using a tape; then we calculated the difference between both sides. Quadriceps strength was assessed with the grading system that ranged from zero to 5 . Grade 5 indicates full strength and grade zero is given when no muscular contraction is detected. ${ }^{9}$

The functional outcome was assessed with use of the Lysholm knee scale. Patients were categorized as excellent (95-100 point), good (84-94), Fair $(65-83)$ and Poor $>65$ points. ${ }^{10}$

\section{Radiological assessment}

Radiographs were examined for assessment of fracture healing in the surgical group and for measurement of the patellar dimensions in both groups.

The fracture was defined as healed if the fracture line is obliterated or bridged. Non-union was defined as progressive widening of the fracture line, displacement of the fragment with or without wire fragmentation. Time to union was estimated from date of surgery to date of fracture healing.

In most recent radiograph for the injured and healthy knees (Fig. 2 and Fig. 3), we measured two of the patellar dimensions (length and thickness) in centimetres and we estimated the ratio between both sides for each patient. The patellar longitudinal length was measured in the lateral view from uppermost to lowermost visible points of the osseous patellar skeleton. The patellar thickness was measured in the axial views as the longest perpendicular line between the anterior and posterior osseous borders of the patella. The radiographs were taken for both sides in the same setting under identical radiographic measures.

\section{Statistical analysis}

The results are expressed as maximum and minimum values, mean and standard deviation (SD). Wilcoxon singed rank test for paired data was used to compare both sides in the same group. Wilcoxon rank sum test (Mann-Whitney U Test) for unpaired data was used to compare the surgical and the conservative groups. Significance was set at $\mathrm{P}<0.05$. Correlation test were performed. The software pro- 
grams used was KyPlot version 2.0 and Microsoft excel 2010.

\section{RESULTS}

All patients returned for the follow-up evaluation at a period-averaged 65.5 months (range: 36-102). Age of the patients at time of the latest examination averaged 17.45 years (range: from 13 - 21.5).

\section{Clinical outcome}

Range of active knee motion of the injured side in the surgical group averaged $0-140^{\circ}(\mathrm{SD}=12.74$, range $0-120^{\circ}$ to $\left.0-155^{\circ}\right)$ compared to $0-149^{\circ}(\mathrm{SD}=6.51$, range $0-140^{\circ}$ to $0-155^{\circ}$ ) in contralateral side. The difference between the two sides was statistically insignificant $(\mathrm{P}=0.18)$. In the conservative group, the range of active knee motion of the injured side averaged $4.28-144.85^{\circ}(\mathrm{SD}=4.49-8.95$, range $10-$ $130^{\circ}$ to $\left.0-155^{\circ}\right)$ compared to $0-152^{\circ}(\mathrm{SD}=2.51$, range $0-150^{\circ}$ to $0-155^{\circ}$ ) in contralateral side. The difference between the two sides was statistically significant $(\mathrm{P}=0.03)$. No extension lags in the surgical group. However, in the conservative group the extension lag averaged $4.3^{\circ}(\mathrm{SD}=4.49$, range $\left.0^{\circ}-10^{\circ}\right)$. The flexion deficit, in the surgical group averaged $9^{\circ}\left(\mathrm{SD}=13.41\right.$, range 0 to $\left.30^{\circ}\right)$ and in the conservative group averaged $7.14^{\circ}(\mathrm{SD}=8.09$, range $0^{\circ}$ to $20^{\circ}$ ). The difference between the two groups was statistically insignificant $(\mathrm{P}=0.9)$.

Thigh girth atrophy, in the surgical group averaged $0.8 \mathrm{~cm}$ (range $0-2$ ) and in the conservative group averaged $1.1 \mathrm{~cm}$ (range 0-3). Full quadriceps strengths were reported in the surgical group; however, one patient of the conservative group reported grade 4 strength (Table 2). The scores of the Lysholm knee scale ${ }^{10}$ in the surgical group averaged 97.2 points ( $\mathrm{SD}=3.89$, range $92-100$ ) and in the conservative group averaged 91.28 points $(\mathrm{SD}=11.17$, range 70-100). The difference between the two group was statistically insignificant $(\mathrm{P}=0.3)$.

Table 2. Clinical outcome for two groups of children with fractured patella treated surgically or conservatively

\begin{tabular}{|c|c|c|c|c|c|c|c|c|c|c|c|c|}
\hline \multirow{3}{*}{$\begin{array}{c}\text { Case } \\
\text { no }\end{array}$} & \multicolumn{6}{|c|}{ Surgical group } & \multicolumn{6}{|c|}{ Conservative group } \\
\hline & \multicolumn{2}{|c|}{ Knee motion } & \multirow[t]{2}{*}{ QS } & \multirow{2}{*}{$\begin{array}{l}\text { Thigh } \\
\text { atrophy }\end{array}$} & \multicolumn{2}{|l|}{ Lysholm scale } & \multicolumn{2}{|c|}{ Knee motion } & \multirow[t]{2}{*}{ QS } & \multirow{2}{*}{$\begin{array}{l}\text { Thigh } \\
\text { atrophy }\end{array}$} & \multicolumn{2}{|c|}{ Lysholm scale } \\
\hline & Injured & Healthy & & & Rating & Points & Injured & Healthy & & & Rating & Points \\
\hline 1 & $0-140^{\circ}$ & $0-155^{\circ}$ & 5 & $1 \mathrm{~cm}$ & Good & 94 & $10-140^{\circ}$ & $0-155^{\circ}$ & 5 & $2 \mathrm{~cm}$ & Good & 84 \\
\hline 2 & $0-145^{\circ}$ & $0-145^{\circ}$ & 5 & $0 \mathrm{~cm}$ & Excellent & 100 & $0-155^{\circ}$ & $0-155^{\circ}$ & 5 & $0 \mathrm{~cm}$ & Excellent & 100 \\
\hline 3 & $0-120^{\circ}$ & $0-150^{\circ}$ & 5 & $2 \mathrm{~cm}$ & Good & 92 & $0-145^{\circ}$ & $0-150^{\circ}$ & 5 & $0 \mathrm{~cm}$ & Excellent & 100 \\
\hline 4 & $0-140^{\circ}$ & $0-140^{\circ}$ & 5 & $0 \mathrm{~cm}$ & Excellent & 100 & $5-140^{\circ}$ & $0-150^{\circ}$ & 5 & $2 \mathrm{~cm}$ & Good & 90 \\
\hline 5 & $0-155^{\circ}$ & $0-155^{\circ}$ & 5 & $1 \mathrm{~cm}$ & Excellent & 100 & $5-150^{\circ}$ & $0-150^{\circ}$ & 5 & $1 \mathrm{~cm}$ & Excellent & 95 \\
\hline 6 & & & & & & & $0-155^{\circ}$ & $0-155^{\circ}$ & 5 & $0 \mathrm{~cm}$ & Excellent & 100 \\
\hline 7 & & & & & & & $10-130^{\circ}$ & $0-150^{\circ}$ & 4 & $3 \mathrm{~cm}$ & Fair & 70 \\
\hline
\end{tabular}

QS = Quadriceps strength

\section{Radiographic outcome}

All fractures in the surgical group healed in a period-averaged 10 weeks (range 8-12). The patellar longitudinal length of injured side in the surgical group averaged $4.32 \mathrm{~cm}(\mathrm{SD}=0.50$, range $3.5-4.8)$ compared to $4.24 \mathrm{~cm}(\mathrm{SD}=0.45$, range $3.5-4.7)$ in contralateral side. The difference between the two sides was statistically insignificant $(\mathrm{P}=0.1)$. In the conservative group, the longitudinal length of the injured side averaged $4.61 \mathrm{~cm}(\mathrm{SD}=0.63$, range 3.8 5.7) compared to $3.82 \mathrm{~cm}(\mathrm{SD}=0.36$, range 3.3-4.3) in contralateral side. The difference between two sides was statistically significant $(\mathrm{P}=0.02)$. Thickness of the injured patella in the surgical group averaged $2.42 \mathrm{~cm}(\mathrm{SD}=0.73$, range 1.9-3.7) compared to $2.26 \mathrm{~cm}(\mathrm{SD}=0.53$, range $1.9-3.2)$ in contralateral side. The difference between two sides was statistically insignificant $(\mathrm{P}=0.1)$. Thickness of the injured patella in the conservative group averaged 1.87 $\mathrm{cm}(\mathrm{SD}=0.19$, range 1.6-2.2) compared to $1.64 \mathrm{~cm}$ $(\mathrm{SD}=0.12$, range $1.5-1.8)$ in the contralateral side. 
The difference between two sides was statistically insignificant $(\mathrm{P}=0.055)$.

We think that estimation of the percentage ratio between the injured and healthy sides for each individual is more expressive than the metric system for displaying of the differences between the groups (Table 3). The patellar longitudinal length of injured side relative to healthy side in the surgical group averaged $101.78 \%(\mathrm{SD}=1.90$, range $100 \%$ to $104.6 \%$ ) and in the conservative group averaged $121.42 \%$ ( $\mathrm{SD}=26.56$, range $100 \%$ to $172.7 \%$ ). The difference between the two groups was statistically significant $(\mathrm{P}=0.04)$. The patellar thickness of injured side relative to healthy side in the surgical group averaged $105.98 \%$ ( $\mathrm{SD}=8.20$, range $100 \%$ to $115.6 \%$ ) and in the conservative group averaged $114.71 \%$ (SD= 17.04 , range $100 \%$ to $137.5 \%$ ). The difference was statistically insignificant $(\mathrm{p}=0.4)$.

Table 3. Radiographically measured patellar dimensions for two groups of children with patellar fractures were treated surgically or conservatively

\begin{tabular}{|c|c|c|c|c|c|c|c|c|c|c|c|c|}
\hline \multirow{3}{*}{$\begin{array}{c}\text { Case } \\
\text { no }\end{array}$} & \multicolumn{6}{|c|}{ Surgical group } & \multicolumn{6}{|c|}{ Conservative group } \\
\hline & \multicolumn{3}{|c|}{ Patellar length $(\mathrm{cm})$} & \multicolumn{3}{|c|}{ Patellar thickness $(\mathrm{cm})$} & \multicolumn{3}{|c|}{ Patellar length $(\mathrm{cm})$} & \multicolumn{3}{|c|}{ Patellar thickness $(\mathrm{cm})$} \\
\hline & Injured & Healthy & LI/LH\% & Injured & Healthy & $\mathrm{TI} / \mathrm{TH} \%$ & Injured & Healthy & $\mathrm{LI} / \mathrm{LH} \%$ & Injured & Healthy & $\mathrm{TI} / \mathrm{TH} \%$ \\
\hline 1 & 4.6 & 4.5 & 102.2 & 2.4 & 2.1 & 114.3 & 4.8 & 3.4 & 141.2 & 2 & 1.5 & 133.3 \\
\hline 2 & 4.2 & 4.2 & 100 & 2 & 2 & 100 & 4.2 & 3.9 & 107.7 & 1.7 & 1.7 & 100 \\
\hline 3 & 4.8 & 4.7 & 102.1 & 3.7 & 3.2 & 115.6 & 4.3 & 4 & 107.5 & 1.9 & 1.8 & 105.5 \\
\hline 4 & 3.5 & 3.5 & 100 & 1.9 & 1.9 & 100 & 5.1 & 4.3 & 118.6 & 1.9 & 1.5 & 126.7 \\
\hline 5 & 4.5 & 4.3 & 104.6 & 2.1 & 2.1 & 100 & 4.4 & 4.1 & 102.3 & 1.6 & 1.6 & 100 \\
\hline 6 & & & & & & & 3.8 & 3.8 & 100 & 1.8 & 1.8 & 100 \\
\hline 7 & & & & & & & 5.7 & 3.3 & 172.7 & 2.2 & 1.6 & 137.5 \\
\hline
\end{tabular}

$\mathrm{LI} / \mathrm{LH} \%=$ the ratio between length of the injured and length of the healthy patella

$\mathrm{TI} / \mathrm{TH} \%=$ the ratio between thickness of the injured and thickness of the healthy patella

Correlation tests confirmed that the extension lag is directly proportional to increase in the patellar longitudinal length [correlation coefficient $(\mathrm{r})=$ 0.872483 ] and the same relation was reported between the flexion deficit and increase in the patellar thickness [correlation coefficient $(r)=0.741423$ ].

\section{DISCUSSION}

The traditional aim for treatment of the patellar fracture is just restoration continuity of the extensor mechanism. However, the progress in perception of the patellar biomechanics renders preservation of its normal dimensions is mandatory. Therefore, the priority, nowadays, should be given to a method that preserves normal patellar geometry.

Tension band wiring and circumferential wiring through adjacent soft tissue are of oldest techniques and are still commonly used for patellar fractures. ${ }^{4,6}$ However, several biomechanical studies indicate that the soft tissues between the wire and the bone allowed separation of the fracture fragments. ${ }^{6,8}$ Accordingly, we believe that these techniques are not suitable for children's patella, which has small osseous skeleton surrounded with thick cartilage. ${ }^{7}$ Furthermore, Scapinelli reported that the circumferential repair may strangle the vessels in their peripatellar course. ${ }^{11}$ For that reasons, we have used the inter-fragmentary wiring technique in which the loop of wire is in direct contact with bone. ${ }^{6}$

Conservative treatment has been recommended for non-displaced patellar fractures. ${ }^{5,712}$ However, patellar elongation was noticed after conservative treatment. ${ }^{4}$ We also reported significant patellar elongation in the group was treated conservatively (Fig. 2a,b). Mechanism of patellar loading can explain patellar elongation. With knee extension patella is loaded primarily in tension; and with knee flexion, its posterior surface is subjected to a compressive force through its contact with the femoral trochlea. Loading of the posterior patellar surface results in tension at its anterior surface, which is ad- 
ditive to that naturally generated by distraction from contraction of the quadriceps..$^{12,13}$

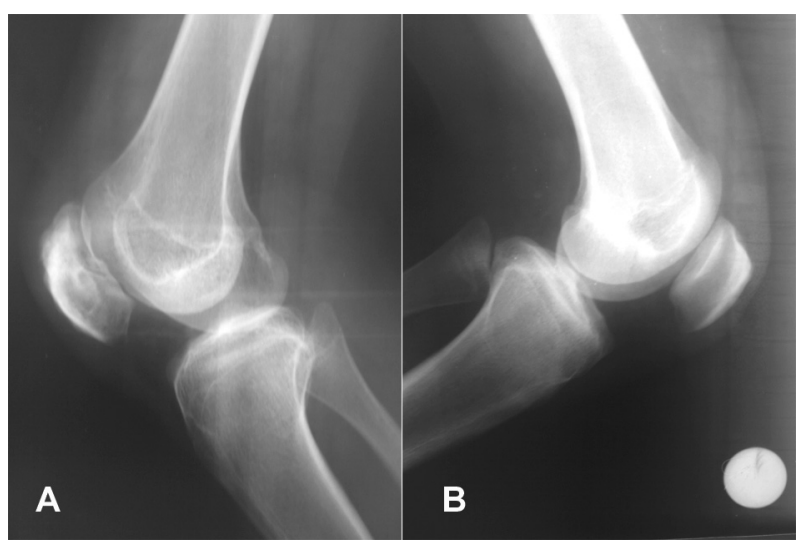

Figure 2-A through 2-D lateral and axial radiograph for both knee of sixteen-years-old male made four years postoperative. The lateral view shows increase of the longitudinal length of the healed left patella that was surgically treated for comminuted fracture (Fig. 2-A) compared to healthy right patella (Fig. 2-B)

The patella functions as a linkage, providing continuity between the quadriceps and the patellar tendons. ${ }^{1}$ Consequently, if the patellar length increased, logically, the length of the quadriceps muscles decrease. Decrease of the basic length of a given muscle reduces the total tension generated by that muscle, expressed as muscular insufficiency. ${ }^{1,3}$ Chronic insufficiency of the quadriceps can lead to intramuscular fibrosis, clinically seen as an extensor lag. ${ }^{3}$ Moreover, chronic insufficiency will also result in limitation of muscular excursion with loss of knee flexion. ${ }^{3}$ In the present study, knees with patellar elongations reported extension lag averaged $4.3^{\circ}$ and a flexion deficit averaged $7.1^{\circ}$.

In contrary to the patellar elongation the merely increase of the patellar thickness will increase the tibial torque but decrease the knee flexion. ${ }^{3}$ In the extended knee position, the patellar action is analogous to a pulley, which displaces the quadriceps anteriorly, thereby increasing its moment arm. In flexion, the patella sinks into the inter-condylar region and produces little anterior displacement of the quadriceps tendon. ${ }^{1}$ Increased patellar thickness (Fig. 2c,d and Fig. 3c,d) will humps route of quadriceps-patellar tendons, clinically seen as flexion deficit. $^{2,3}$

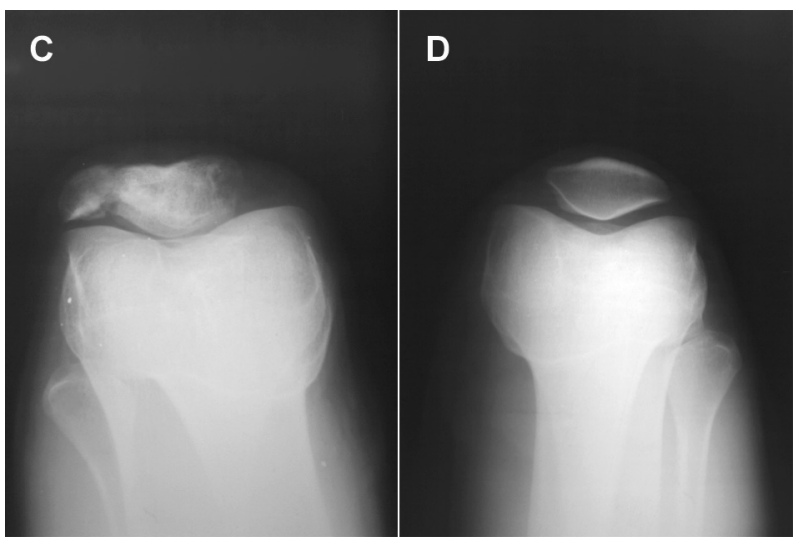

Figure 2-C and D the axial view shows increased thickness of the left patella (Fig. 2-C) compared to healthy right patella (Fig. 2-D)

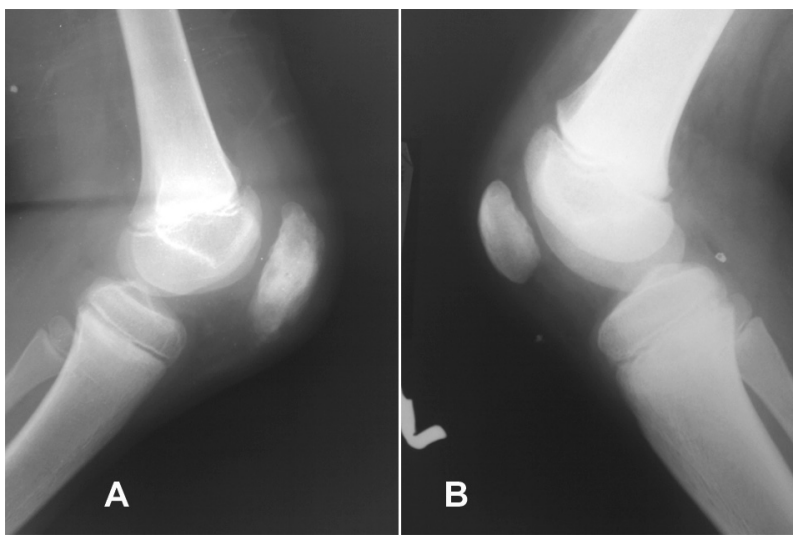

Figure 3-A through 3-D lateral and axial radiograph for both knee of thirteen-years-old male made three years post injury. The lateral view shows increase of the longitudinal length of right patella that was conservatively treated for comminuted fracture (Fig. 3-A) compared to healthy left patella (Fig. 3-B)

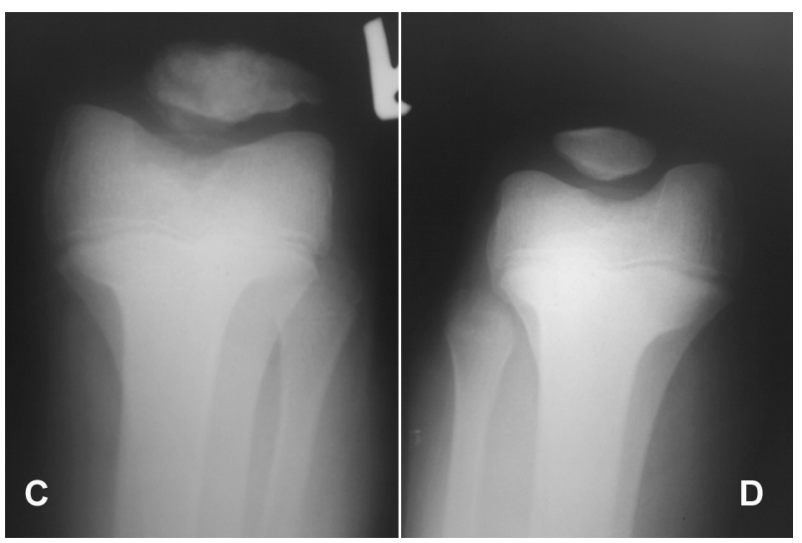

Figure 3-C and D the axial view shows increased thickness of the right patella (Fig. 3-C) compared to healthy left patella (Fig. 3-D) 
Fracture patterns as well as the treatment methods played a role in the reported changes of the patellar dimensions. The comminuted fractures, which were treated conservatively (Fig. 3), had the worst results (Tables 2,3). Although the inter-fragmentary wiring technique preserved to great extent the patellar length, however failed to preserve thickness of the comminuted patellar fracture (Fig. 2). Intraoperatively, we have noticed firmness of the articular surface of the patellar fragments while the anterior surface of the cartilage envelope, which received the trauma, appeared frayed. Considering of the patellar loading mechanism, ${ }^{12}$ the frayed anterior envelope, theoretically, encouraged the osseous skeleton to grow anteriorly, thereby the patellar thickness increased.

In conclusion, the inter-fragmentary wiring technique preserved to great extent the longitudinal patellar length but failed in preservation of the patellar thickness particularly in the comminuted patellar fractures. Patellar elongation caused extension lag and flexion deficit while the mere increase of the patellar thickness caused only flexion deficit.

Since no clear evidence renders the inter-fragmentary wiring the preferred technique for treatment of the patellar fractures in children, additional prospective randomized studies are needed to better define merits of this technique among other surgical techniques.

Conflict of interest: The authors declare that they have no conflict of interest

\section{Acknowledgement}

I am most grateful to pharmacist Abdulsamad Mahran- Sohag Teaching Hospital-for making of the statistics of the present study.

\section{REFERENCES}

1. Kaufer H. Mechanical function of the patella. J Bone Joint Surg Am 1971; 53(8): 1551-60.

2. Yoo JH, Yi SR, Kim JH. The geometry of patella and patellar tendon measured on Knee MRI. Surg Radiol Anat 2007; 29(8):623-8.

3. Wendt PP, Johnson RP. A study of quadriceps excursion, torque, and the effect of patellectomy on cadaver knees. J Bone Joint Surg Am 1985; 67(5): 726-32.

4. Houghton,GR, Acroyd CE. Sleeve fractures of the patella in children. A report of three cases. J Bone Joint Surg Br 1979; 61(2):165-168.

5. Schmal H, Strohm PC, Niemeyer P, Reising K, Kuminack K, Südkamp NP. Fractures of the patella in children and adolescents. Acta Orthop Belg 2010; 76(5):644-50.

6. Weber MJ, Janecki CJ, McLeod P, Nelson CL, Thompson JA Efficacy of various forms of fixation of transverse fractures of the patella. J Bone Joint Surg Am 1980;62(2):215-20.

7. Beaty JH, Kumar A. Current concepts review. Fractures about the knee in children. J Bone Joint Surg Am 1994; 76(12):1870-80.

8. Baran O, Manisali M, Cecen B. Anatomical and biomechanical evaluation of the tension band technique in patellar fractures. Int Orthop 2009; 33(4):1113-7.

9. Sapega AA. Muscle performance evaluation in orthopaedic practice. J Bone Joint Surg Am 1990;72(10):1562-74.

10. Lysholm J, Gillquist J. Evaluation of knee ligament surgery results with special emphasis on use of a scoring scale. Am J Sports Med 1982; 10(1):150-4.

11. Scapinelli R. Blood supply of the human patella: Its relation to ischaemic necrosis after fracture. J. Bone Joint Surg Br 1967; 49:563-70.

12. Carpenter JE, Kasman R, Matthews LS Fractures of the Patella. J Bone Joint Surg Am 1993; 75(2):150-6.

13. Goldstein SA, Coale E, Weiss AP, Grossnickle M, Meller B, Matthews LS. Patellar surface strain. J Orthop Res 1986; 4(3): 372-7. 